\title{
Workers' Remittance Inflow, Financial Development and Economic Growth: A Study on Bangladesh
}

\author{
Mahedi Masuduzzaman ${ }^{1}$ \\ ${ }^{1}$ Ministry of Finance, Finance Division, Bangladesh \\ Correspondence: Mahedi Masuduzzaman, Ministry of Finance, Finance Division, Bangladesh. E-mail: \\ mahedimasuduzzaman@hotmail.com
}

Received: May 29, 2014

Accepted: June 11, 2014

Online Published: July 25, 2014

doi:10.5539/ijef.v6n8p247

URL: http://dx.doi.org/10.5539/ijef.v6n8p247

\begin{abstract}
The objective of this article is to analyze the role of remittance on economic growth and to investigate the interaction of remittance with the financed development of Bangladesh using annual data, relatively liberalized regime spanning from 1981 to 2013. This study employed the mostly used Johansen co-integration test along with vector error correction model to reveal both the short-run and the long-run association between remittance-growth and remittance-financed development. Granger Causality tests are also used to explore the possible endogenous relationship between remittance-growth and remittance-financed development. This study finds a long run positive relationship between inflow of remittance and gross domestic products (GDP) indicating that remittance will be more likely to contribute to longer-term growth in Bangladesh. It is also revealed that remittances have a significant positive effect on financial development. Therefore, this study posits that the inflow of workers' remittance matters for countries like Bangladesh, which has a relatively growing economy and a developing financial sector. The paper also discusses a number of policy issues arising from the results of the analysis in relation to remittance in association with managing migration and remittance, skilled development of the migrants, Dutch disease effect, returnee expatriates and gender issues. While examining the channels the direct impact of remittance on poverty reduction (household welfare) remains an area of research for the future. The outcome of this study will be a clear understanding of the key factors affecting workers' remittance, growth and financial development, which will be relevant to policy makers to have detailed appraisals of remittance polices and their expected economic impact on Bangladesh and other remittance recipients country as well.
\end{abstract}

Keywords: remittances, financial development, growth, Bangladesh, co-integration, VECM, endogeniety test

\section{Introduction}

The workers' remittance-transfer by international migrants to their countries of origin has been one of the largest sources of financial flows to developing countries, often overshadowing the traditional sources such as official development assistance and private capital flows (Ali, et al., 2014; Kipyegonb et al, 2012; Aggarwal et al., 2011) Consequently, the impact of workers' remittance on economic activities has received increasing interest from both researchers and policy makers. Indeed, some have argued that remittances have a positive and significant effect in economic growth (Kumar, 2013). Despite evident success, some studies have found that remittances can have a deleterious impact on economic growth suggesting that they are compensatory in nature (Chami et al., 2003). According to the World Bank, the inflow of remittance to developing countries has estimated at $\$ 404$ billion in 2013 that grew by 3.5 per cent compared to 2012. The growth of inward remittance to developing countries is expected to accelerate further in the coming years and it may increase up to \$516 billion in 2016 to an annual average growth of 8.4 percent. However, it is believed that a huge amount of inward remittance remains unrecorded which could be more than 54 percent that is coming from informal avenues like hand carried by friends and relatives and unofficial system (World Bank, 2006).

In the context of Bangladesh, the remittance from migrant workers create one of the most noteworthy sources of foreign exchange and are playing an important role in economic activities of Bangladesh. Bangladesh is one of the core suppliers of migrant workers who are spread almost all over the world and one of the top 10 remittance receiving countries (8th in 2013) in the world (World Bank, 2014). The inflow of remittance has increased gradually in recent years from $\$ 2.8$ billion in 2002 to $\$ 13.8$ billion in 2013 , which is over 11 percent of Gross 
Domestic Products (GDP) and almost half of export earnings (Bangladesh Bank, 2013). Therefore, it may be assumed that remittance contribute to economic growth through their positive impact on consumption, savings, or investment.

Despite the increase in migration and remittance flows and the vast implication of remittance on economic growth and financial system of Bangladesh, this area is not well explored. Literature to be found is mainly based on descriptive approaches. A few studies concentrate on remittance, financial development and economic growth with limited econometric approaches using the data starting from early seventies, when remittance flow was too little. It is worth mentioning that although remittance to Bangladesh remarkably began in the mid-1970s, the country achieved a stable trend of remittance from early 1980s, when the regime embarked on trade liberalization by abandoning the fixed exchange rate. Moreover, economic growth and financial system of Bangladesh also began to thrive in the early eighties (Paul \& Das, 2011). In this end, how does and at what extent the inflow of remittance respond to the changes in economic activities and financial system of Bangladesh remains an open empirical question. Moreover, understanding the remittance inflow pattern that could impact the financial system of Bangladesh, using Johansen test, Vector Error Correction Model (VECM) and endogeniety test with annual data, relatively liberalized regime spanning from 1981 to 2013, could be useful for policy makers, researchers and all other stakeholders.

Section one of this study is the introductory part. The rest of the study is structured in six sections. The second section of the study will present an overview of related literatures that will give us a sound conception of the facts and section three gives an overview on recent trend of migrant workers and remittances of Bangladesh as well as world perspectives. Section four provides an avenue regarding the research methodological approach and the relevant information on the time series data sets that are used for this study, while section five discussed the empirical results. Moreover, section six provides conclusion and finally, section seven points out the possible recommendations of the study.

\section{Brief Literature Review}

Reviewing the existing literature is mostly focused on the issues of economic growth, financial development and poverty alleviation effects on remittance inflow for the remittance receiving developing countries (Barajas et al., 2009; Chami et al., 2003; Chowdhury, 2011). This short literature review is divided into two segments: presenting the cross-country and panel works, and finally concentrating on Bangladesh issues.

In a study on 94 developing countries, Barajas et al. (2009) found that there was no significant impact of remittance on poverty reduction. Apart from that, the impact of remittance on direct economic growth is insignificant but may have small indirect growth effect (Rao \& Hassan, 2011). However, Chami et al. (2003) finds negative effect of remittance on overall economic growth because it diminishes the ability to work of the remittance recipient family's able persons. In contrast, research conducted by Adams and Page (2005) finds that remittance inflow in 71 developing countries reduces the level, depth and severity of poverty. Maimbo and Ratha (2005) claimed that rural people from developing countries reduce their poverty level using workers' remittance. Using panel data spanning the period of 1993-2003 in developing Asia-pacific countries Jongwanich (2007) claims that workers' remittances have a positive but marginal impact on economic growth and poverty reduction. The positive effect of remittance on poverty reduction in Sub-Saran African countries through increased income and higher standard of living was investigated by Gupta et al. (2009).

Buch and Kuckulenz (2010) find that remittances have a positive impact on welfare enhancing effect, such as consumption, capital investment, education and health. Employing panel data for 33 African countries over the 1990-2005 period, Anyanwu and Erhijakpor (2010) claim that the inflows of remittances have a positive impact on poverty reduction in 33 African countries. This study also argues that the reduction of poverty depends on poverty measurement procedures. It has also investigated that sometimes job stability of the migrated workers and the economic activities of the remittances sending country have significant influences on remittance flows to receiving developing country (Maldonado et al., 2011). Guha (2013) finds that international remittances have a direct impact on the micro level household decision making, primarily with respect to the consumption and labor supply decisions.

Sometimes the volatility of remittance creates problem in the recipient's economy. Craigwell et al. (2010) assert that remittance can play a key role in mitigating the effect of adverse output shocks but exert no significant influence on consumption and investment volatility. Bayangos and Jansen (2011) show that workers' migration and remittance inflow have a significant impact on competitiveness that goes beyond the traditional exchange rate effect in Philippines. This study also argues that large number of emigration cuts the numbers of labor force and the receipt of remittance further reduce labor supply. 
In the previous studies it has been investigated that remittances not only influence economic growth but also financial system of a particular country. Giuliano and Ruiz-Arranz (2009) find that remittance boost growth in countries with less developed financial systems by providing an alternative way to finance investment and helping overcome liquidity constraints. Moreover, the inflow of remittance influences the growth of financial development in developing countries (Aggarwal et al., 2011). It is possible to convert the remittance into deposits resulting in more funds available for lending by commercial bank to the private sector credit. In turns, financial development enhances economic growth (Misati \& Nyamongo, 2011). Furthermore, remittance encouraged growth in less financially developed countries by providing an alternative way to finance investment (Giuliano \& Ruiz-Arranz, 2009). Using annual data for the period 1980-2009 of 36 African countries, Kipyegon et al. (2012) find remittance emerged as an important source of growth and financial development. However, volatility of remittances appears to have a negative effect on the growth of countries in Africa. Anzoategui et al. (2014) investigate the impact of remittance on financial inclusion using household-level survey data for El Salvador and finds that remittances have a positive impact on financial inclusion by promoting the use of deposit accounts.

Paul and Das (2011) claim there is no evidence on remittance-led growth in the short-run but finds a long run positive relationship between remittance and GDP in Bangladesh using annual data during the period of 1979 to 2009. Using annual data spanning from 1976 to 2010 and employing Autoregressive Distributed Lag (ARDL) bounds testing approach Paul et al. (2011) find that remittance does not appear to be a long-run forcing variable to the explanation of Bangladesh's economic growth. Furthermore, applying co-integration and Vector Error Correction Model (VECM) Chowdhury (2011) explored that the increasing flow of remittance is positively and significantly expanding and deepening the financial sector of Bangladesh over the 1971-2008 period. However, the starting period of remittance data in this study is somewhat questionable due to data availability. Siddique et al. (2012), working with annual data spanning from 1976 to 2006 in three South Asian countries, Bangladesh, India and Sri-Lanka finds that growth in remittances do lead to economic growth in Bangladesh. In case of India, there seems to be no causal relationship between growth in remittance and economic growth; however, in Sri-Lanka, economic growth influences growth in remittance and vice-versa. The sample period use by this study is too short for proper econometric analysis. Finally, Uddin and Sjo (2013) investigates the effects of remittance and financial development on economic growth using annual data for the period of 1976-2011 and applying Johansen's vector auto regression (VAR) method. This study finds that the flow of remittance and the expansion of financial sector drive the growth in Gross Domestic Products in the long run, while remittance act as a shock absorber to income changes in the short run. Actually, Uddin and Sjo (2013) have examined the impact of remittance and financial development on economic growth simultaneously. However, the current study will explore the impact of remittance on economic growth and financial development of Bangladesh separately.

In summary, the aforesaid study found different results of remittance impact on economic growth, poverty reduction and financial development mainly due to the methods and techniques and duration of data that are used. In case of Bangladesh, study has been conducted using the data starting from early seventies, when remittance flow was too little. On the other hand, this study chooses a relatively liberalized regime data starting from 1981 when the country achieved a stable trend of remittance. Doing study in a sample includes very little remittance flow and unsaturated financial system may offer spurious results.

\section{Contextual Information of the Study}

\subsection{Remittances Compared with Other Resource Flows: Global Perspectives}

Remittance, funds received from migrants working abroad to developing countries have grown dramatically in recent years. According to recent data released by the International Monetary Fund (IMF) and the World Bank, global remittance flow is estimated at $\$ 542$ billion in 2013. Remittance remain a key source of external resource flows for developing countries, far exceeding official development assistance and are more stable than Foreign Direct Investment (FDI) over the years (Figure 1). 


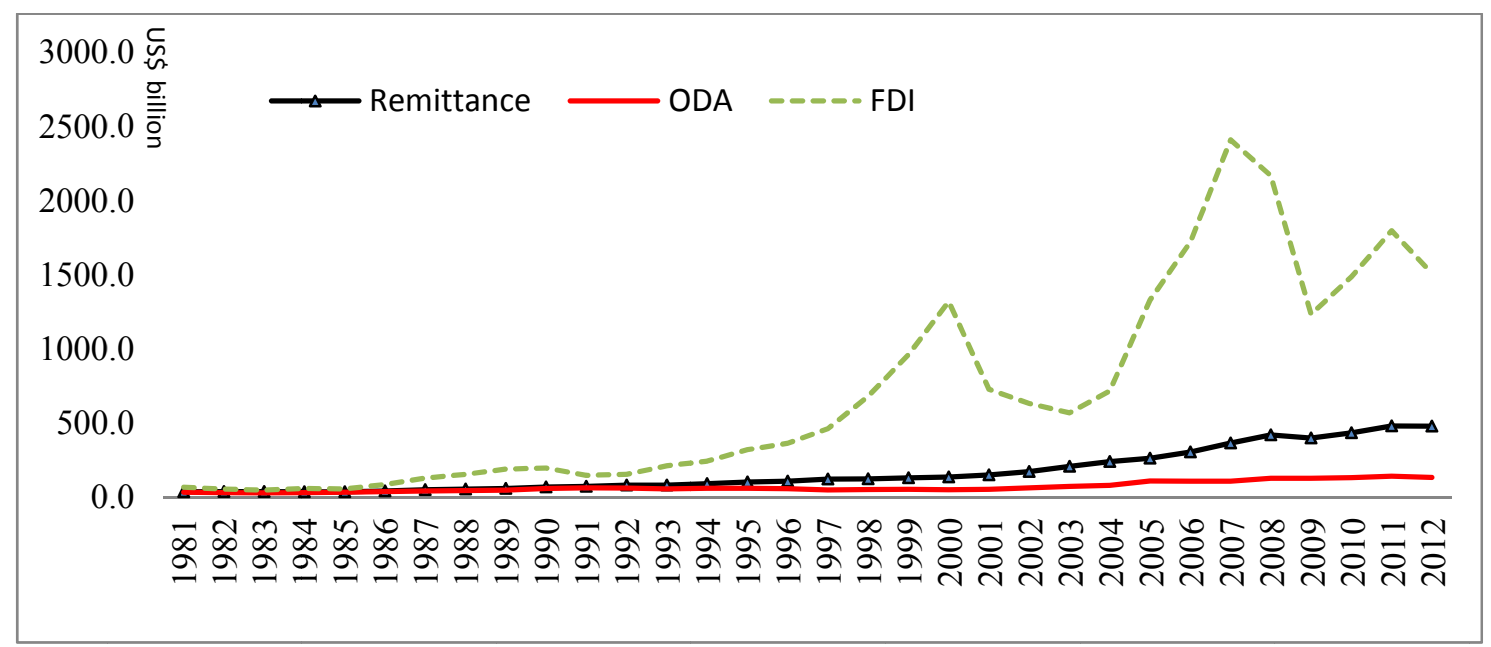

Figure 1. Global remittances and other resource flows are large and growing

Source: World Bank, World Development Indicators (WDI).

The growth of global remittance trends increased over the years. At the same time, growth of remittances in India, Sri Lanka and Bangladesh also increases with little fluctuations (Figure 2).

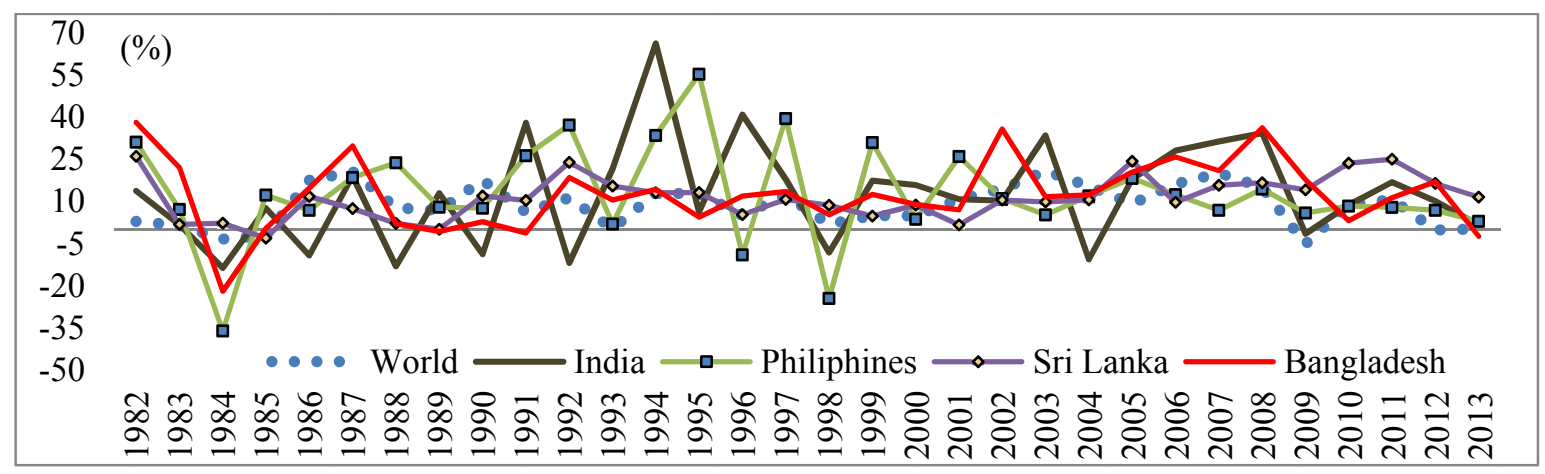

Figure 2. Global growth (\%) trend of remittances

Source: World Bank, WDI.

In 2013, India remained as the largest recipient of officially recorded remittance in the world and received about $\$ 70$ billion followed by China around $\$ 60$ billion and Philippines $\$ 25$ billion, while Bangladesh was the $8^{\text {th }}$ largest remittance recipient (Figure 3).

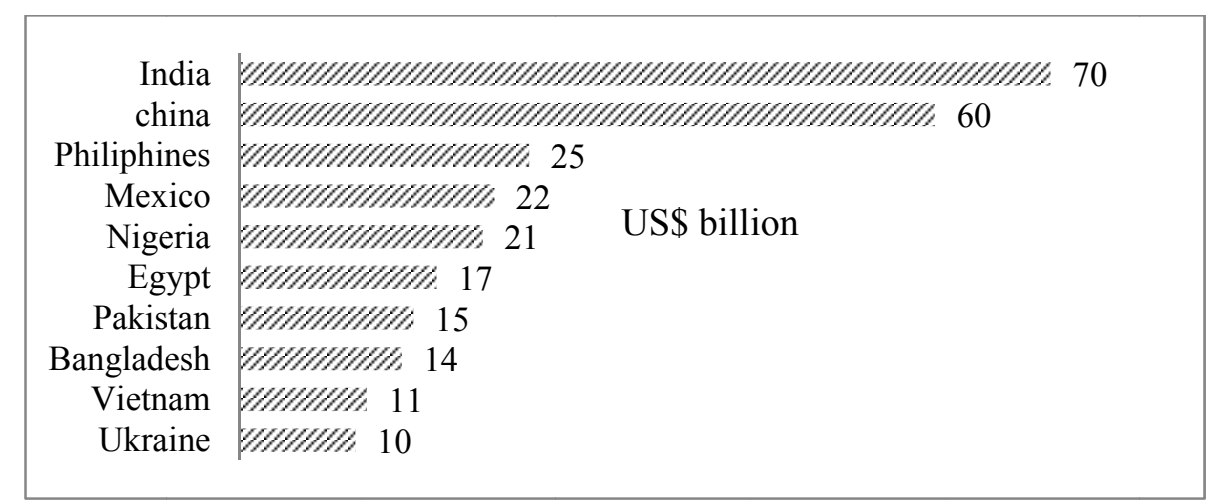

Figure 3. Most 10 Remittance recipients' countries, 2013 
It is estimated that, about 232 million people (3.2 percent of the world population) live outside their countries of birth in 2013 which was about 33 percent increase compared to 175 million in 2000 (United Nations). The most desired destination for the migrant workers was the United States of America (USA) and total immigration was 43 million in 2010 followed by the Russian Federation of around 12 million and Germany 11 million (Figure 4).

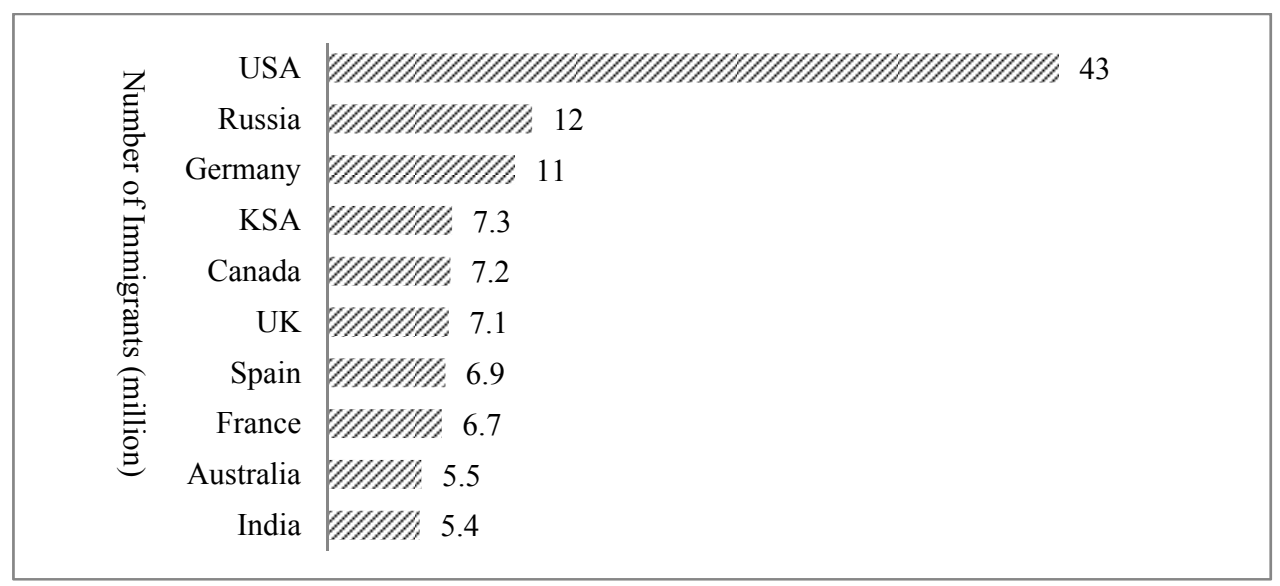

Figure 4. Top immigration countries, Number of immigrants

Source: World Bank, Migration and Remittances Fact book, 2011.

The following figure 5 depicts that Mexico is considered a huge labor surplus country. In 2010, about 12 million Mexican migrants' were working aboard followed by India 11.5 million and Russia 11 million. Bangladesh was the 6th largest emigrants' country and 5.4 million migrants' were working abroad at that time.

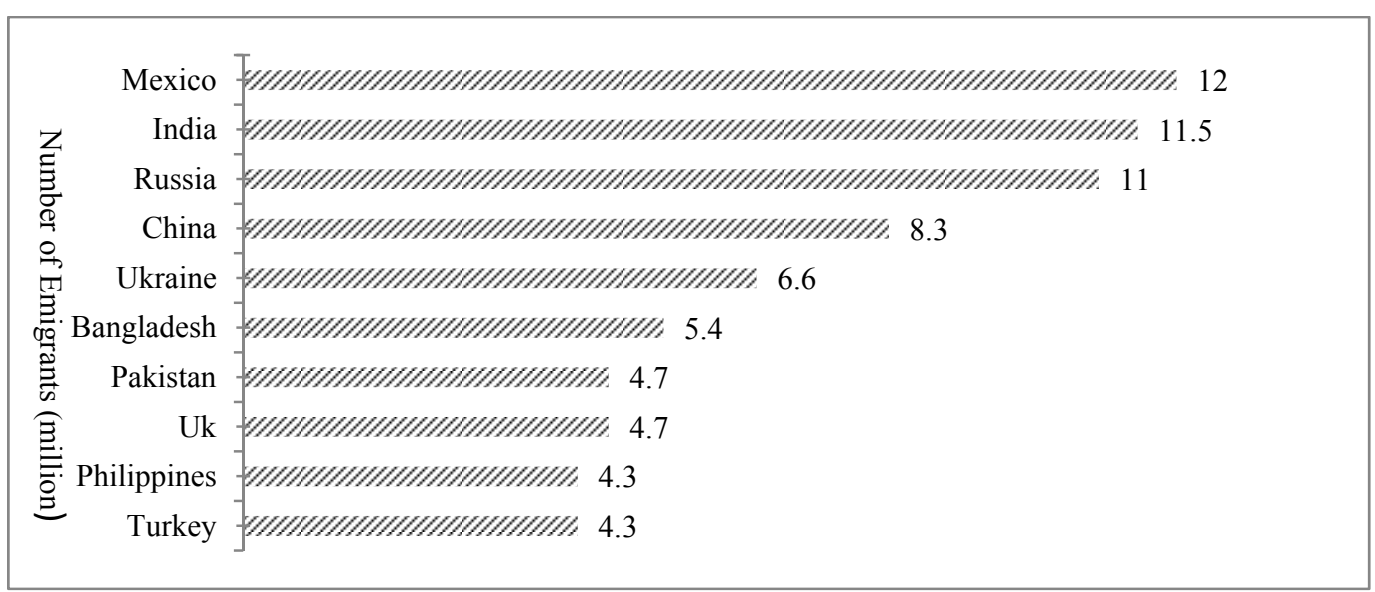

Figure 5. Top emigration countries, 2010, Number of emigrants (Million)

Source: World Bank, Migration and Remittances Fact book, 2011.

The inflow of remittances exceeds the foreign exchange reserves in different developing countries (Figure 6). In case of Tajikistan inflow of workers' remittances was 11 times larger than its foreign exchange reserve followed by Sudan with 208 percent in 2013 . 


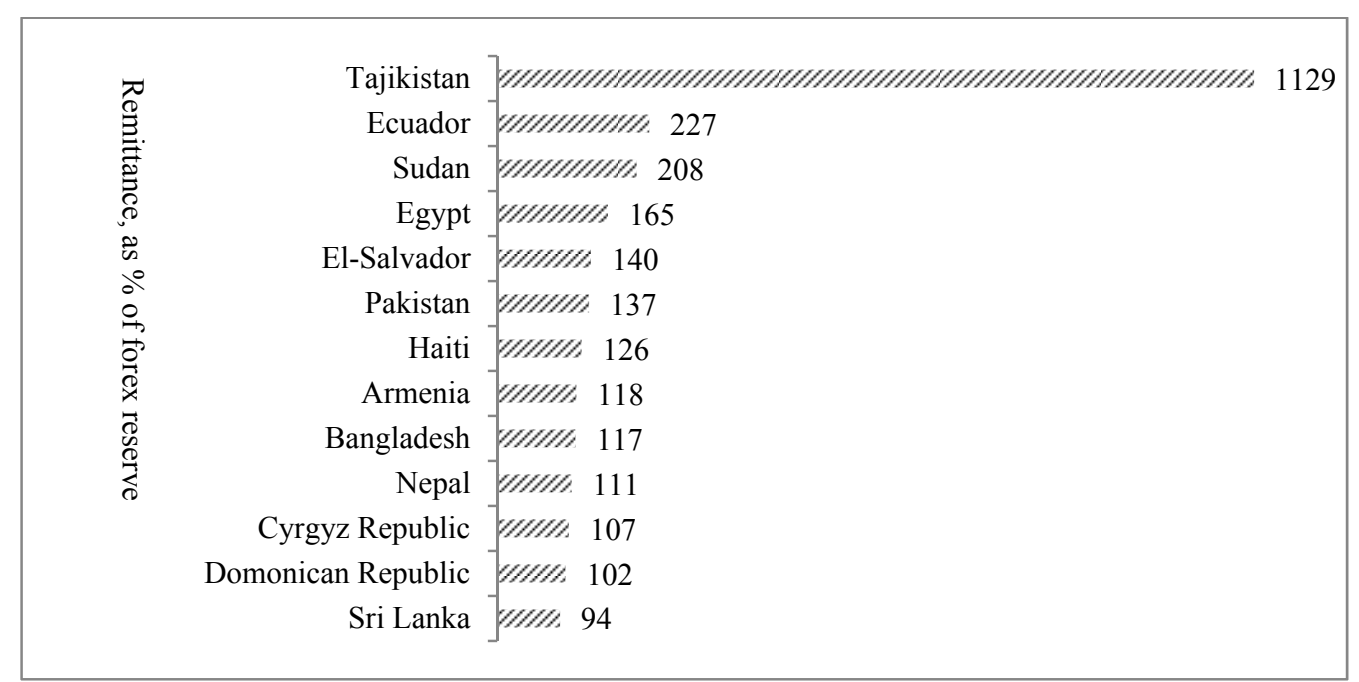

Figure 6. Remittance, as \% of foreign exchange reserve

Source: World Bank, Migration and Development Brief, October, 2013.

\subsection{Workers' Migration and Remittance Inflow in Bangladesh: Historical Perspective}

Bangladesh has a long history of workers' migration in the world. Sri-Lankan mythology stated that Singhala communities, the original citizens of Sri-Lanka, are believed to have first migrated to Sri Lanka from Bangladesh (Siddique, 2004). During the British period, people from Bangladesh also migrated to Assam and Burma. The then Burma was one of the major destination and a significant number of people had migrated to Bhurma, as, at that time Burma was the thriving economy (Chowdhury, 2011). Since, the early eighteen century and onwards, sailors originating from the southeastern part of Bangladesh and landless farmers of northern Sylhet district found employment in the British merchant navy and travelled different parts of the world (Bruyn and Kuddus, 2005). Working on ships or even as stowaways, they migrated to a number of countries mainly to the United Kingdom (UK) and the United States of America (USA) (Siddique, 2004).

The second phase of migration to the UK from the then east Pakistan started in the mid-fifties, when British Government introduced a scheme to encourage labor migration from its erstwhile colonies, as there was acute labor shortage after the Second World War. In case of the USA, the second migration wave gained momentum in the early 1960s. However, the nature of migration in the USA was significantly different compared to that of UK, as most migrants were students and professionals. A large number of students, after finishing their studies, who chose to remain in the US. After the independence of Bangladesh in 1971, along with the US and the UK, a large number of Bangladeshis migrated to Canada, Italy, France, Australia, Germany, Greece and other EU countries as well. Bangladeshi migrants sought to look for job opportunities in the Middle East countries mainly the Kingdom of Saudi Arabia (KSA), Kuwait, Oman and United Arab Emirates (UAE) in the late 1970s. Apart from that a tendency to find employment in some Eastern Asian countries like Japan, Malaysia, Singapore and Hong Kong was observed in the early 1990s and the process is still going on strongly.

\subsection{Workers' Migration and Inward Remittances: Bangladesh Scenario}

Bangladesh has emerged as one of the leading remittance recipient countries through the export of its labor services to the Middle East, Europe, America and South East Asian countries since the late 1970s. Remittance income increased from $\$ 23.7$ million in 1976 to $\$ 13.8$ billion in 2013 which accounts for about 3 percent of the global remittances and contributing to over 11 per cent of GDP of the country. This large inflow of remittance has massive development effects in the country. According to the "Ministry of Expatriates' Welfare and Overseas Employment" around 8.7 million Bangladeshi workers are working in 159 different countries. However, there is no data available that how many workers return at home. In Bangladesh, remittance remain a key source of foreign exchange, which are far exceeding the official development assistance. Figure 7 depicts that as percentage of GDP, official development assistance is decreasing and remittance increasing over time that reflect in balance of payments. 


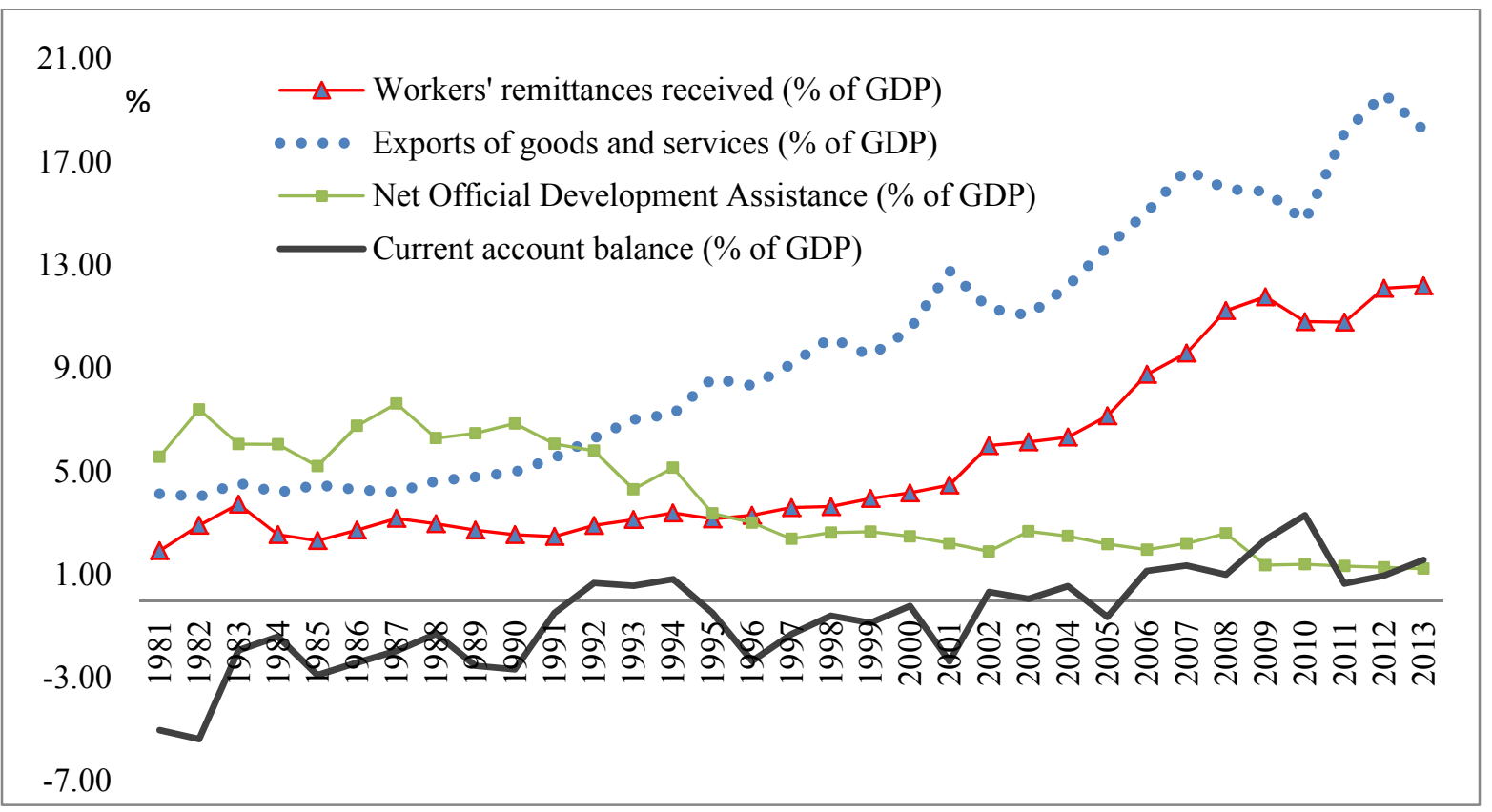

Figure 7. Inflow of remittances and other foreign exchange earnings to Bangladesh (1981-2013)

Source: Bangladesh Bank and World Bank.

Figure 8 shows the annual growth rate of GDP, the inflow of workers' remittance and outflow of migrant workers during the 1982-2013 periods. Bangladesh has continued its impressive growth trajectory over the years. However, it is not clear how much is contributed by workers' remittance on economic activities of Bangladesh. The growth of the inflow of workers' remittance has increased over the years. However, the growth rate became negative in 1984, 1991 and 2013. The growth of outflow of migrant workers has increased but fluctuated over the years.

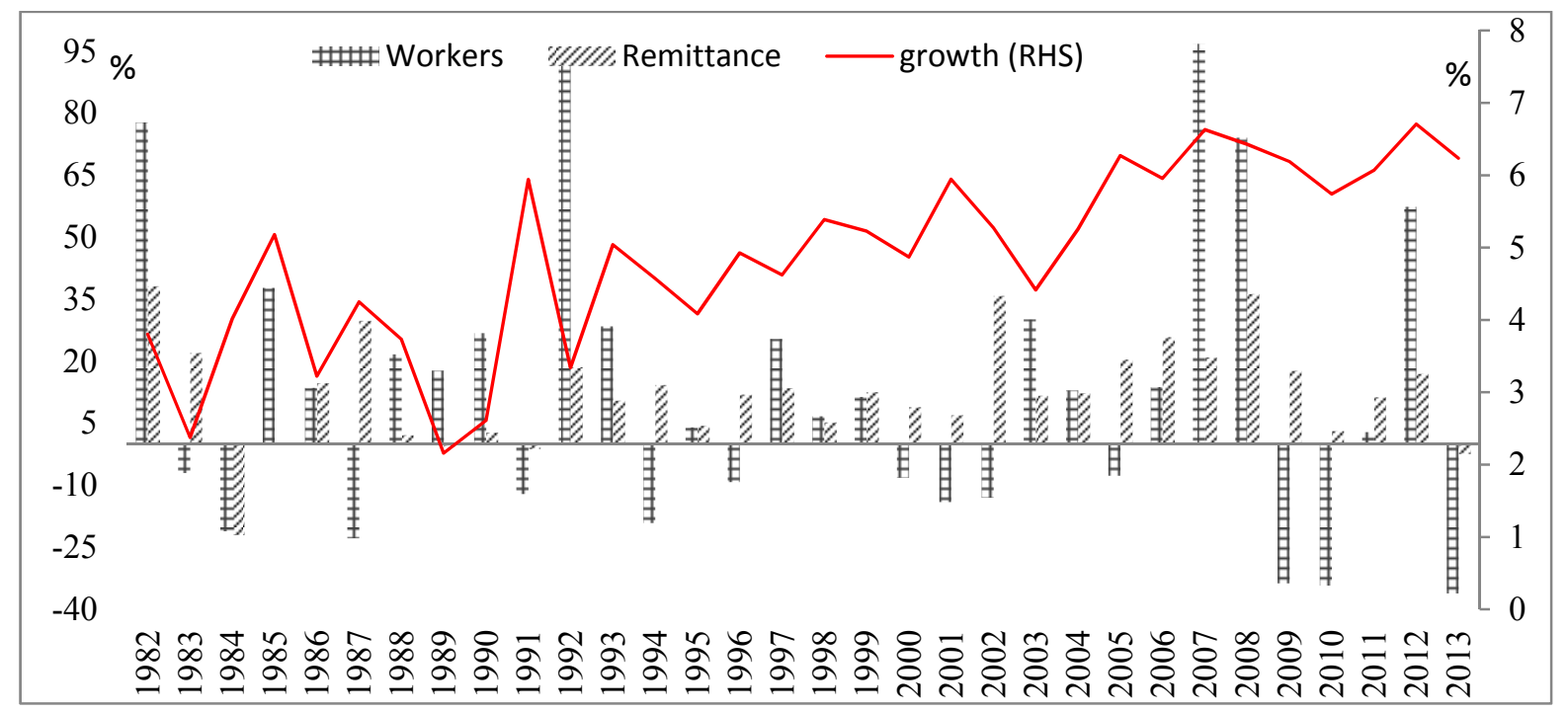

Figure 8. Trends in the GDP growth rate, annual inflow of workers remittance and outflow of migrant workers

Sources: Authors' calculation based on Bureau of Manpower, Employment \& Training and Bangladesh Bureau of Statistics data.

The main destination of the Bangladeshi workers is the Kingdom of Saudi Arabia (KSA). Since 1976, it is estimated that about 30 percent of migrated workers destination was KSA followed by UAE 26 percent and Oman 10 percent (Figure 9). The main source of remittance of Bangladesh is migrant workers living in Saudi Arabia, which contributed 30 percent of total remittances, followed by UAE 16 percent and United States of 
America (USA) 14 percent in the period spanning from 1994 to 2013 (Figure 10).

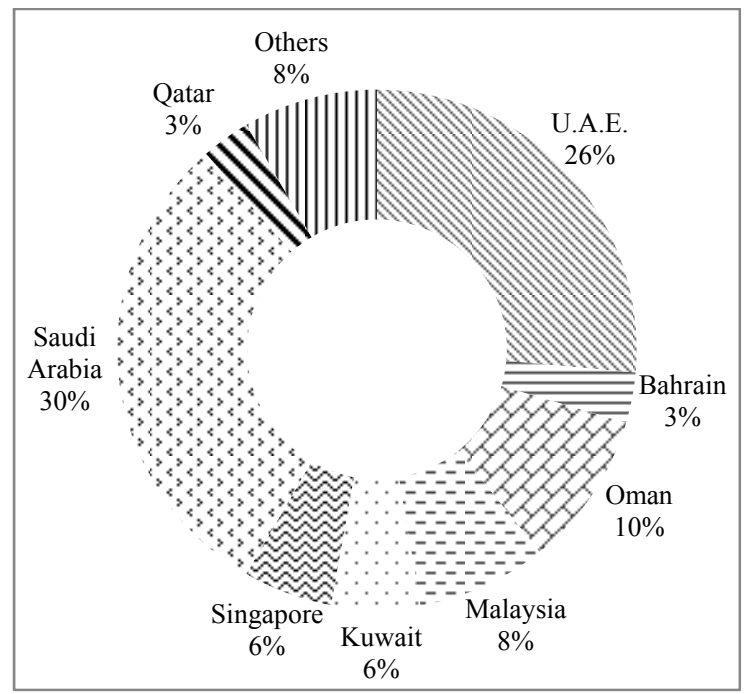

Figure 9. Overseas employment (1976-2013)

Source: Authors' calculation based on Bureau of Manpower, Employment \& Training's data.

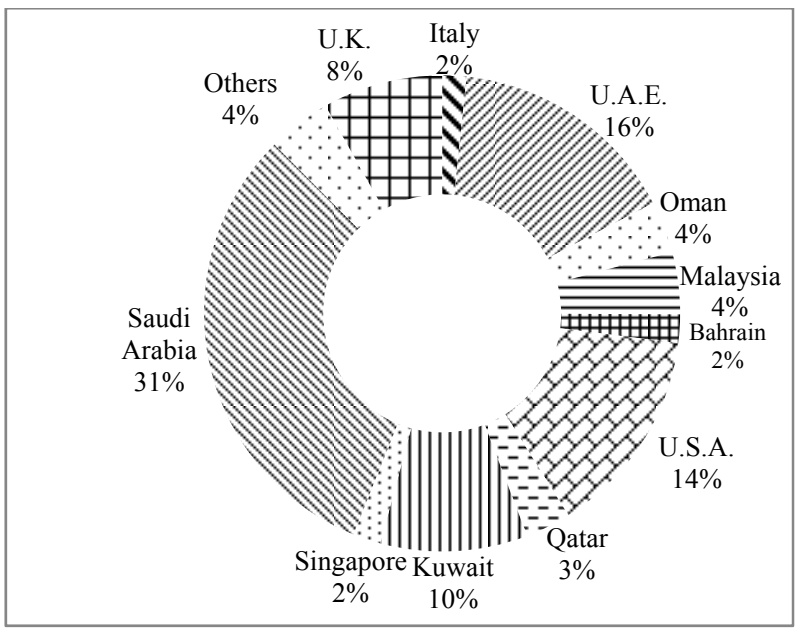

Figure 10. Inward remittances from different countries (1994-2013)

Source: Authors' calculation based on Bureau of Manpower, Employment \& Training's data.

Bangladesh has classified temporary migrant population into different categories such as less skilled, semi-skilled, skilled and professional. Figure 11 demonstrates that from 1976 to 2013, about 51 percent people are less skilled, 15 percent semi-skilled, 31 percent skilled and only about 3 percent are professional migrated to different destinations. The skill composition of those who migrated in 2013, in general, indicates a consistent level of comparatively high proportion of less skilled and semi-skilled migrant workers. Although, the number of migrant workers increased significantly, the proportion of professional migrants decreased in 2013 (Figure 12). During the same period, less skilled and semi-skilled categories remained almost unchanged. 


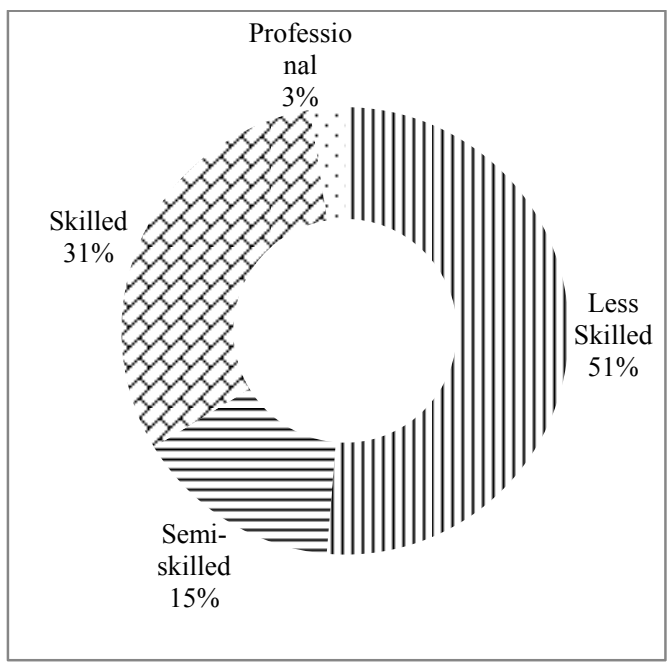

Figure 11. Category-wise emigrants for overseas employment (1976-2013)

Source: Authors' calculation based on Bureau of Manpower, Employment \& Training's data.

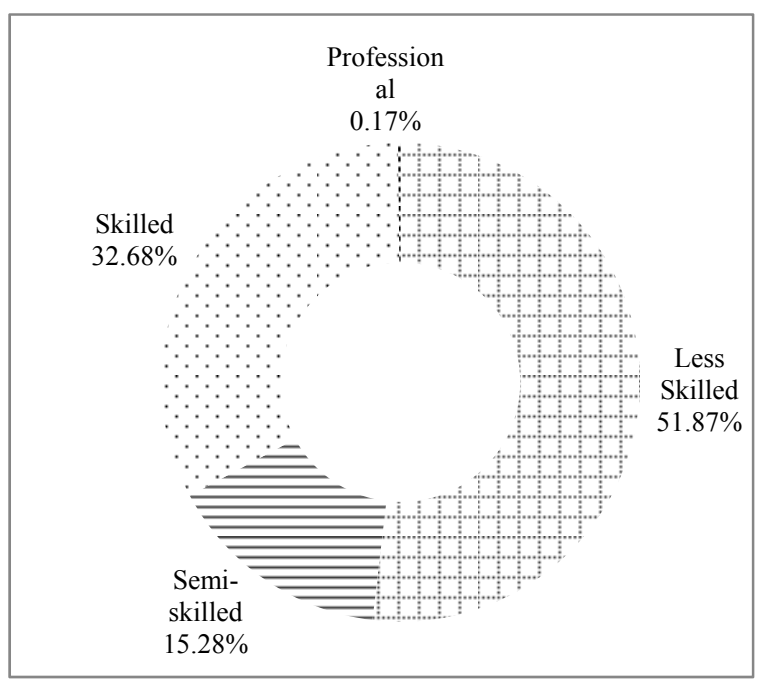

Figure 12. Category-wise emigrants for overseas employment (2013)

Source: Authors' calculation based on Bureau of Manpower, Employment \&Training's data.

\subsection{Workers Migration: Gender Issues}

Female migration from Bangladesh was an uncommon phenomenon; however, the scenario has been changing since 1991. From, 1991 to 2013 about 0.3 million female migrated for overseas employment of which 29 percent's destination was Lebanon followed by UAE 25 percent and Jordan 17 percent (Figure 13). However, Bangladeshi workers are predominantly male, only 3.7 percent of the female migrated between 1991 to 2013. Nonetheless, the scenario changed slightly as, female migrants constitute 0.17 million among a total of 2.5 million migrants between 2009 to 2013, which is over 7 per cent of the total migrants of Bangladesh (table 1). In the recent years, the growth of male migrants declined but female migrants increased notably (Figure 14). 


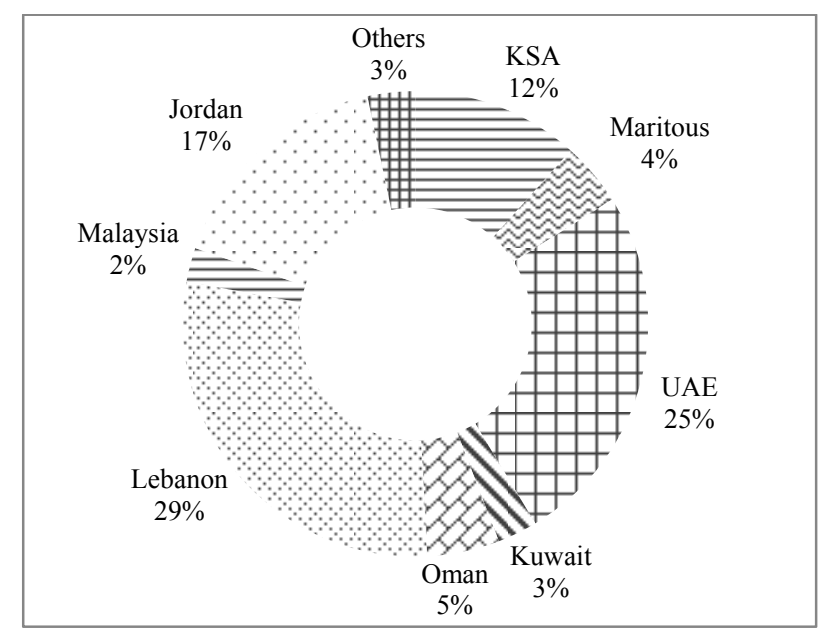

Figure 13. Female emigrants for overseas employment in different destinations (1991-2013)

Source: Authors' calculation based on Bureau of Manpower, Employment \& Training's data.

Table 1. Female migration trends from 2009-2013

\begin{tabular}{cccc}
\hline Period & Number of total migrants & Number & $\begin{array}{c}\text { Female migrants } \\
\text { \% of total migrants }\end{array}$ \\
\hline 2009 & 475278 & 22224 & 4.7 \\
2010 & 390702 & 27706 & 7.1 \\
2011 & 568062 & 30579 & 5.4 \\
2012 & 607798 & 37304 & 6.1 \\
2013 & 409253 & 56400 & 13.8 \\
Total & 2451093 & 174213 & 7.1 \\
\hline
\end{tabular}

Source: Authors' calculation based on Bureau of Manpower, Employment \& Training's data.

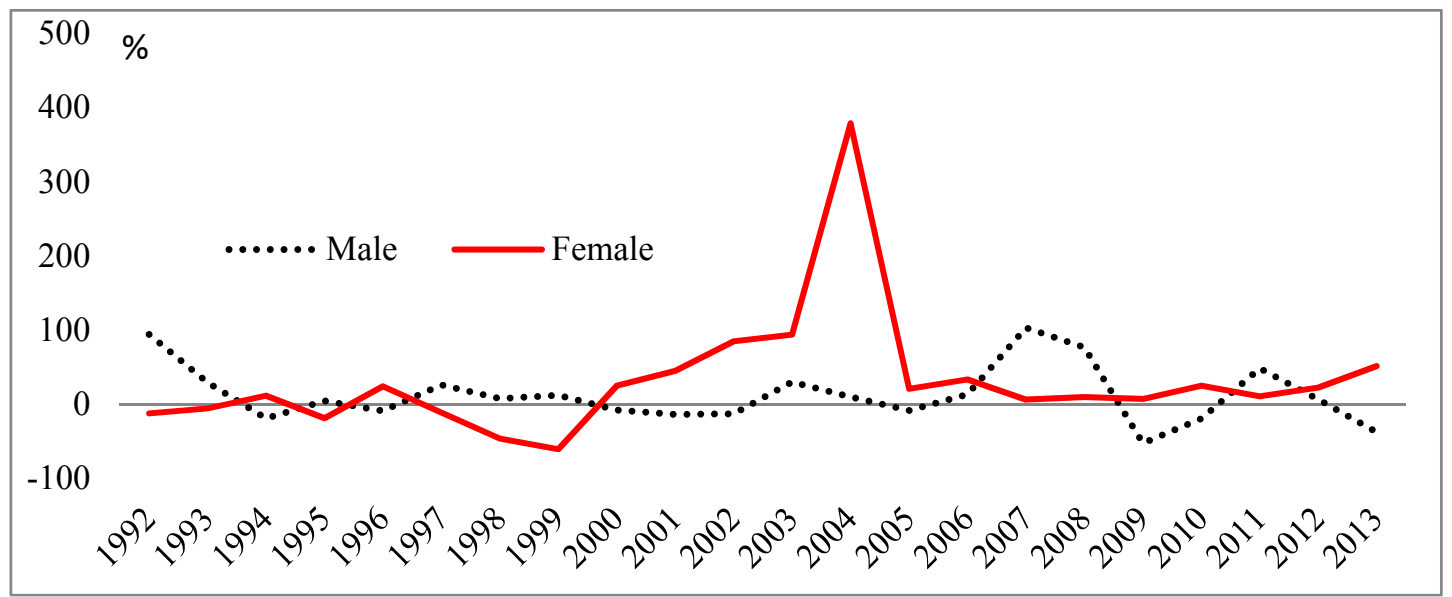

Figure 14. Growth of male and female emigrants for overseas employment (1992-2013)

Source: Authors' calculation based on Bureau of Manpower, Employment \& Training's data.

\section{Data and Empirical Model}

Although remittance to Bangladesh remarkably began in the mid-1970s, the country achieved a stable trend of remittances in the early 1980s, when the regime embarked on trade liberalization by abandoning the fixed exchange rate. Apart from that, economic growth and financial system of Bangladesh also began to thrive in the early eighties (Paul \& Das, 2011). Doing research in a sample includes very little remittance flow and unsaturated financial system may offer spurious results. In this consideration, the empirical analysis of the study is conducted by using annual time series data starting from 1981. The basic data used in this study is obtained 
from various sources such as World Bank's World Development Indicators (WDI) database, Bangladesh Bank (Central Bank of Bangladesh), Bangladesh Bureau of Statistics (BBS) and Bangladesh 'Bureau of Manpower, Employment and Training (BMET).

This study is based on the assumption that economic growth causes an inflow of capital in the form of workers' remittance because Bangladesh has received a huge amount of remittance since the early 1980s, which is likely to have long-term implications for the economy. Based on previous studies on remittance and economic growth, such as Chami et al. (2005), we can express the baseline specification in the following form:

$$
G D P P C_{t}=\alpha+\beta_{1} \text { Remit }_{t}+\beta_{2} X_{t}+\varepsilon_{t}
$$

Where, $t$ refers to the time period from 1981 to 2013 . The dependent variable is the real GDP per capita (GDPPC) used here is in US dollars (2005 prices) and Remit is the key explanatory variable referring to the ratio of remittance to GDP. $\mathrm{X}$ is a vector of control variables found in standard growth models and having possible impact on the economic growth in Bangladesh. $\varepsilon_{t}$ is the error term. The matrix $\mathrm{X}$ in equation (1) includes inflation, openness to international trade (open), population growth (popu_gr) etc. Inflation (Inf) measured as the annual percentage change in the consumption price index. Openness to international trade, defined as the ratio of the sum of exports plus imports of goods to GDP and population growth, defined as the annual percentage changes of Bangladesh population. To explore the relationship between remittance and financial development this study models the financial development as a function of remittance in a manner consistent with Aggarwal et al. (2011) as:

$$
F D_{t}=\alpha^{\prime}+\beta_{1}^{\prime} \text { Remit }_{t}+\beta_{2}^{\prime} X_{t}^{\prime}+\varepsilon_{t}^{\prime}
$$

Where, $t$ refers to the time period from 1981 to 2013. Remit is the key explanatory variable referring to the ratio of remittance to GDP. X is a vector of control variables having possible impact on the financial sector's development in Bangladesh. $\varepsilon_{t}^{\prime}$ is the error term and FD stands for financial development.

This study uses a variety of measures to proxy for financial development (FD), which are standard measures of financial depth used in the literature (Aggarwal et al., 2011; King \& Levine, 1993). Firstly, liquid liabilities of the financial system (money supply (M2) to GDP) which is considered the broadest measure of financial intermediation and includes three types of financial institutions: the central bank, deposit money banks, and other financial institutions. Secondly, private domestic deposit (deposit) to GDP and finally, bank credit (credit) to GDP. It is expected that the association between remittances and financial development is to be positive because increasing trend of remittance flows may directly enhance deposit, credit and money availability (Chowdhury, 2011). Nonetheless, steady flow of remittances may decrease the saving efforts of the recipient families and hinder the intermediation of the financial sector (Aggarwal et al., 2011).

The matrix $\mathrm{X}$ in equation (2) refers to a set of variables that the literature as found to be related to financial development. Actually, $\mathrm{X}$ is consisting of country size, inflation, real interest rate, openness to international trade etc. In all estimations we control for country size, defined as the log of real GDP in US dollars. In all models, we also control for inflation, measured as the annual percentage change in the GDP deflator. Previous studies have shown that inflation distorts economic agents' decision-making regarding nominal magnitudes, discouraging financial intermediation, and promoting saving in real assets (Aggarwal et al., 2011). An increasing price level lowers the real gain from investing in the financial assets and a negative relationship is generally expected between price level and financial development (Boyd et al., 2001). The relationship between interest rate and financial development is ambiguous and is an empirical issue for an individual country. Real interest rate is used in all three equations. Following conventional measure, openness in goods market is measured by exports plus imports as a ratio of GDP. Increased openness in the goods is expected to increase use of numerous financial products and services and tends to expand the sector (Chowdhury, 2011).

Generally, we see that time series data is non-stationary, but the model can only be built once the given time series are stationary. According to 'Engle and Granger' (1987), if independent series are stationary then the series are said to be co-integrated. To investigate, whether the given time series are stationary, there are several procedures found in the econometric literature. It is evident that each test has its own merits and demerits. This study uses two tests such as Augmented Dickey Fuller (1979) and Phillips Peron (1988) test to avoid the criticisms of individual test.

If the chosen variables are found to be stationary, testing them for co-integration will be followed as per Johansen (1991) Maximum Likelihood (JML) Co-integration and Vector Error Correction Model (VECM) as Gonzalo (1994), in his Monte Carlo study, found that JML has the best finite sample properties among the alternative methods and estimators. VECM also has the stronger ability to incorporate the potential long run 
dynamic relation and better forecasting power (Chowdhury, 2011). To determine the presence and the number of co-integrating vectors, we used the maximum Eigen value and Trace test. The inflow of remittance and growth model can be represented by the following equation:

$$
G D P P C_{t}=\alpha+\beta_{1} \text { Remit }_{t}+\beta_{2} \text { Inf }_{t}+\beta_{3} \text { Open }_{t}+\beta_{4} \text { Popu_gr } r_{t}+\varepsilon_{t}
$$

Again, the inflow of remittances and different versions of the financial development model for Bangladesh can be represented by the following equations:

\subsection{Endogeniety Test}

$$
\begin{gathered}
\text { Credit }_{t}=\alpha^{\prime}+\beta_{1}^{\prime} \text { Remit }_{t}+\beta_{2}^{\prime} G D P_{t}+\beta_{3}^{\prime} \text { Inf }_{t}+\beta_{4}^{\prime} \text { Open }_{t}+\beta_{5}^{\prime} \text { int_rate }_{t}+\varepsilon_{t}^{\prime} \\
\text { Depo }_{t}=\alpha^{\prime \prime}+\gamma_{1}^{\prime} \text { Remit }_{t}+\gamma_{2}^{\prime} G D P_{t}+\gamma_{3}^{\prime} \text { Inf }_{t}+\gamma_{4}^{\prime} \text { Open }_{t}+\gamma_{5}^{\prime} \text { int_rate }_{t}+\varepsilon_{t}^{\prime \prime} \\
M 2_{t}=\alpha^{\prime \prime \prime}+\delta_{1}^{\prime} \text { Remit }_{t}+\delta_{2}^{\prime} G D P_{t}+\delta_{3}^{\prime} \text { Inf }_{t}+\delta_{4}^{\prime} \text { Open }_{t}+\delta_{5}^{\prime} \text { int_rate }_{t}+\varepsilon_{t}^{\prime \prime \prime}
\end{gathered}
$$

After the Vector Error Correction (VEC) estimation, this study will proceed to unveil endogeniety testing of the chosen variables. To investigate the possible endogenous relationship between remittance-growth and remittance-financed development, we perform the Grange Causality test to examine whether financial system of Bangladeshis encouraging the rapid growth of remittance and economic growth is encouraging the rapid growth of inflow of remittance. The causality model can be express as following way.

$$
\begin{gathered}
\Delta G D P P C_{t}=\beta_{0}+\sum_{i=1}^{n} \beta_{1 i} \Delta G D P P C_{t-1}+\sum_{i=1}^{m} \beta_{2 i} \Delta \operatorname{Re} m i t_{t-1}+\varepsilon_{1 t} \\
\Delta \operatorname{Re} \text { mit }_{t}=\delta_{0}+\sum_{i=1}^{n} \delta_{1 i} \Delta \operatorname{Re} \text { mit }_{t-1}+\sum_{i=1}^{m} \delta_{2 i} \Delta G D P P C_{t-1}+\varepsilon_{2 t} \\
\Delta F D_{t}=\alpha_{0}+\sum_{i=1}^{n} \alpha_{1 i} \Delta G D P P C_{t-1}+\sum_{i=1}^{m} \alpha_{2 i} \Delta \operatorname{Re} m i t_{t-1}+\varepsilon_{3 t} \\
\Delta \operatorname{Re} \text { mit }_{t}=\gamma_{0}+\sum_{i=1}^{n} \gamma_{1 i} \Delta \operatorname{Re} m i t_{t-1}+\sum_{i=1}^{m} \gamma_{2 i} \Delta F D_{t-1}+\varepsilon_{4 t}
\end{gathered}
$$

Where $\Delta=$ First difference operator, $\varepsilon_{1 t}, \varepsilon_{2 t}, \varepsilon_{3 t}, \varepsilon_{4 t}$, is the disturbance terms, $\mathrm{n}$ represents the number of lag length. $\chi^{2}$-statistic (F-test) is used to test each of the variables. If null hypothesisis rejected, it implies that two variables Re mit $_{t}$ and $G D P P C_{t}$ are co-integrated and either Re mit $_{t}$ must Granger cause $G D P P C_{t}$ or $G D P P C_{t}$ Granger cause Re $m i t_{t}$. Similarly, if two variables Re $m i t_{t}$ and $F D_{t}$ are co-integrated and either Re $m i t_{t}$ must Granger cause $F D_{t}$ or $F D_{t}$ Granger cause Re mit . Where $F D_{t}$ represents (i) M2-money supply, (ii) deposit-private domestic deposit to GDP and (iii) credit-bank credit (private sector) to GDP.

\section{Empirical Results}

\subsection{Remittances and Growth}

As per the methodology, the stationarity of the time series is investigated by applying both Augmented Dickey Fuller (1979) and Philips Perron (1988) tests. Table 2 exhibits the results of unit root tests at levels and the first differences of the chosen variables, where evidence was found in favor of the null hypothesis that all series contain unit roots at level. However, we reject the null hypothesis for the first differences of all series. Therefore, it is concluded that all the series are integrated of order 1 i.e. I (1). These properties qualify the variables to be examined in the Johansen co-integration test whose results are presented in Table-3. The decision on the lag length is made by running the variables in an unrestricted Vector Auto-regression (VAR). The long run elasticity relating to the key explanatory variables and their t-ratios are reported in table 3 along with co-integration test. Based on maximum Eigen value and Trace tests, co-integration results indicate the presence of long run relationship among the variables. It should be mentioned here that the values of GDPPC is normalized to one. This means that remittance flow is positively and significantly enhancing the economic growth in Bangladesh. Workers' remittances appear to have a positive and statistically significant impact on growth in the long run. From table-3, it can be also seen that one percentage point increase in remittance suggests 1.4 percentage point increase in GDPPC. This result is consistent with Kumar (2013); Das, A. and Paul (2011) and Kipyegon et al. (2012). 
Table 2. Unit root test results

\begin{tabular}{|c|c|c|c|c|}
\hline \multirow{2}{*}{ Variables } & \multicolumn{2}{|c|}{$\mathrm{ADF}$} & \multicolumn{2}{|c|}{ Phillips and Perron } \\
\hline & Level & First difference & Level & First difference \\
\hline GDPPC & $0.03(0.99)$ & $-5.44 *(0.00)$ & $-0.30(0.98)$ & $-5.44 *(0.00)$ \\
\hline Remittance & $-1.79(0.68)$ & $-5.38 *(0.00)$ & $-1.83(0.66)$ & $-9.65 *(0.00)$ \\
\hline Inflation & $-3.10(0.12)$ & $-6.46 *(0.00)$ & $-3.14(0.12)$ & $-16.5 *(0.00)$ \\
\hline Openness & $-3.07(0.13)$ & $-6.66 *(0.00)$ & $-3.01(0.15)$ & $-6.70 *(0.00)$ \\
\hline Population growth & $-3.10(0.12)$ & $-4.33 *(0.00)$ & $-2.14(0.50)$ & $-4.46 *(0.00)$ \\
\hline Credit & $-2.00(0.57)$ & $-4.47 *(0.00)$ & $-1.96(0.63)$ & $-4.38 *(0.00)$ \\
\hline Deposit & $-0.77(0.81)$ & $-4.99 *(0.00)$ & $-2.72(0.25)$ & $-3.6^{* *}(0.04)$ \\
\hline M2 & $-0.94(0.76)$ & $-4.52 *(0.00)$ & $-0.93(0.75)$ & $-4.46 *(0.00)$ \\
\hline GDP & $-0.43(0.98)$ & $-5.88 *(0.00)$ & $-0.92(0.94)$ & $-5.88 *(0.00)$ \\
\hline Real interest rates & $-1.73(0.71)$ & $-6.02 *(0.00)$ & $-1.48(0.81)$ & $-12.3 *(0.00)$ \\
\hline
\end{tabular}

Note. The Augmented Dickey Fuller (ADF) critical values are based on McKinnon and optimal lag is chosen on the basis of the Schwarz Information Criterion (SIC). The null hypothesis for both ADF and Philips Perron (PP) tests in corresponding series has a unit root. The number of the bracket ( ) indicates probability. * and ** the rejection of null hypothesis of non-stationary at $1 \%$ and $5 \%$ percent significant level respectively.

Table 3. Johansen's co-integration test

\begin{tabular}{cccccccc}
\hline \multicolumn{7}{l}{ Variables: GDPPC, Remittance, Inflation, Openness and Population growth 1981 to 2013} \\
\hline Hypothesis & $\lambda_{\text {trace }}$ & $05 \%$ Critical Value & P-values & $\lambda_{\max }$ & $05 \%$ Critical Value & p-values \\
\hline VAR(1) & $\mathrm{r}=0$ & 83.91 & $69.81^{*}$ & 0.00 & $41.77 *$ & 33.87 & 0.00 \\
& $\mathrm{r} \leq 1$ & 42.13 & 47.85 & 0.15 & 19.10 & 27.58 & 0.40 \\
$\mathrm{r} \leq 2$ & 23.03 & 29.79 & 0.24 & 17.79 & 21.13 & 0.13 \\
& $\mathrm{r} \leq 3$ & 5.23 & 15.49 & 0.78 & 5.22 & 14.26 & 0.71 \\
$\mathrm{r} \leq 4$ & 0.01 & 3.84 & 0.93 & 0.01 & 3.84 & 0.93 \\
\hline
\end{tabular}

Note. $*$ denotes rejection of the hypothesis at the 1 per cent significant level.

In the short run, remittances flows have positive impact on per capita GDP but do not have statistically significant at 5 percent level. Actually, it has weak impact on per capita GDP at 10 percent significant level. Inflation and population growth have negative impact on growth. Impact of inflation on per capita GDP is weak as the co-efficient is small and significant at 10 per cent level. The impact of population growth on per capita GDP is statistically insignificant. Since, the variables are co-integrated in the long run; there exists an error correction mechanism which brings together the long run relationship and its short run dynamic adjustments. The error correction term, which measures the speed at which prior deviations from the equilibrium are corrected, has the correct negative sign and is significant at 5 percent level, but indicating a relatively slow convergence to long-run equilibrium (table 4).

Table 4. Results for error correction model for GDPPC and remittances in Bangladesh (1981-2013)

Dependent Variable: $\triangle \mathrm{GDPPC}$

\begin{tabular}{lllllllll}
\hline$E C M_{t-1}$ & $\Delta G D P P C_{t-1}$ & $\Delta$ Remi $_{t-1}$ & $\Delta \operatorname{Inf}_{t-1}$ & $\Delta$ Oppen $_{t-1}$ & $\Delta$ Popu_gr $_{t-1}$ & Constant & AdjR & F-stat \\
\hline-0.089 & 0.47 & 0.12 & -0.01 & 0.04 & -0.03 & 0.04 & 32.98 & 1.98 \\
$(-1.97)^{*}$ & $(2.69)^{*}$ & $(1.69)^{* *}$ & $(-1.87)^{* *}$ & $(0.45)$ & $(-0.26)$ & $(3.28)^{*}$ & &
\end{tabular}

Note. $*$ denotes rejection of the hypothesis at the 5 percent significant level. $* *$ denotes rejection of the hypothesis at the $10 \%$ significant level.

\subsection{Endogienity Test in Case of Growth}

This study assumes that remittances are exogenously determined. However, it is perceived that remittance flow can be influenced by growth. This study performs the Granger Causality test to examine whether economic 
growth of Bangladeshis encouraging the rapid growth of remittance. The test results are reported in Table-5. Our results demonstrate that growth cause remittance at 1 per cent confidence level. However, the reverse is not true.

Table 5. Pairwise granger causality Test between remittance inflow and economic growth

\begin{tabular}{lccc}
\hline Null Hypothesis: & Obs & F-Statistic & Prob. \\
\hline Remittance does not Granger Cause GDPPC & 31 & 0.57784 & 0.5682 \\
GDPPC does not Granger Cause Remittance & 31 & $6.31274 *$ & 0.0058 \\
\hline
\end{tabular}

Note. * denotes rejection of the hypothesis at the 5 percent significant level.

\subsection{Remittance and Financial Development}

The long run relationship between financial development and the workers' remittance inflow are presented in table-6. The values of financial development indicators such as credit, deposit and money supply are normalized to one. The empirical result of the multivariate Johansen co-integration test supports the presence of at least one co-integrating vector in all equations. The null hypothesis 'the remittance inflows and the financial developments are co-integrated $(\mathrm{r}=0)$ against the alternative of one co-integrating vector $(\mathrm{r}<1)$ ' is rejected because the trace statistic (120.2) value exceeds the corresponding 05 percent critical value (95.75) and the maximum Eigen value statistic (50.6) also produces same result, as value of the maximum Eigen statistic exceed the corresponding 5 percent critical value (40.1). This implies that, remittance flow is positively and significantly enhancing the financial development of Bangladesh. Workers' remittances appear to have a positive and statistically significant impact on all the financial development equations in the long run. From Table-6, it can be also seen that one percentage point increase in remittances suggests more than one percentage point increase in credit and money supply except deposit equation. The results of this study are consistent with findings of Aggarwal, 2011and Kipyegon et al. (2012) and Chowdhury (2011).

Table 6. Johansen's co-integration test

Panel A.

\begin{tabular}{cccccccc}
\hline \multicolumn{7}{l}{ Variables: Credit, Remittance, GDP, Inflation, Openness and real interest rate 1981 to 2013} \\
\hline & Hypothesis & $\lambda_{\text {trace }}$ & 05\% Critical Value & P-values & $\lambda_{\max }$ & 05\% Critical Value & p-values \\
\hline VAR(1) & $\mathrm{r}=0$ & $120.20^{*}$ & 95.75 & 0.00 & $50.64^{*}$ & 40.07 & 0.00 \\
& $\mathrm{r} \leq 1$ & 69.55 & 69.81 & 0.06 & 30.91 & 33.87 & 0.10 \\
& $\mathrm{r} \leq 2$ & 38.64 & 47.85 & 0.27 & 20.90 & 27.58 & 0.28 \\
& $\mathrm{r} \leq 3$ & 17.73 & 29.79 & 0.58 & 9.89 & 21.13 & 0.75 \\
& $\mathrm{r} \leq 4$ & 7.84 & 15.49 & 0.48 & 6.22 & 14.26 & 0.58 \\
\hline
\end{tabular}

LR estimates Credit= 4.41 Remittance -7.07GDP -1.39 Inflation+ 4.42 Openness +0.02 Real interest rate

$(6.56) * \quad(-5.26) * \quad(-5.48) * \quad(3.73) * \quad(0.42)$

Panel B.

\begin{tabular}{|c|c|c|c|c|c|c|c|}
\hline \multicolumn{8}{|c|}{ Variables: Bank deposit, Remittance, GDP, Inflation, Openness and real interest rate 1981 to 2013} \\
\hline & Hypothesis & $\lambda_{\text {trace }}$ & $05 \%$ Critical Value & P-values & $\lambda_{\max }$ & $05 \%$ Critical Value & p-values \\
\hline \multirow[t]{6}{*}{ VAR(1) } & $\mathrm{r}=0$ & $146.36^{*}$ & 95.75 & 0.00 & $59.29 *$ & 40.07 & 0.00 \\
\hline & $\mathrm{r} \leq 1$ & $87.06 *$ & 69.81 & 0.00 & $40.02 *$ & 33.87 & 0.10 \\
\hline & $\mathrm{r} \leq 2$ & 47.04 & 47.85 & 0.06 & 22.51 & 27.58 & 0.19 \\
\hline & $r \leq 3$ & 24.52 & 29.79 & 0.17 & 13.70 & 21.13 & 0.38 \\
\hline & $r \leq 4$ & 10.81 & 15.49 & 0.22 & 9.84 & 14.26 & 0.22 \\
\hline & $\mathrm{r} \leq 5$ & 0.97 & 3.84 & 0.32 & 0.97 & 3.84 & 0.32 \\
\hline \multicolumn{8}{|c|}{ LR estimates Bank deposit $=0.39$ Remittance+0.67 GDP -0.13 Inflation- 0.31 Openness +0.004 Real interest rate } \\
\hline & & & * $\quad(7.17) *$ & $(-6.51)^{*}$ & $(4.55) *$ & (1.32) & \\
\hline
\end{tabular}


Panel C.

\begin{tabular}{|c|c|c|c|c|c|c|c|}
\hline \multicolumn{8}{|c|}{ Variables: M2, Remittance, GDP, Inflation, Openness and real interest rate 1981 to 2013} \\
\hline & Hypothesis & $\lambda_{\text {trace }}$ & $05 \%$ Critical Value & P-values & $\lambda_{\max }$ & $05 \%$ Critical Value & p-values \\
\hline \multirow[t]{6}{*}{$\operatorname{VAR}(1)$} & $\mathrm{r}=0$ & $112.82 *$ & 95.75 & 0.00 & $45.04 *$ & 40.07 & 0.01 \\
\hline & $\mathrm{r} \leq 1$ & 67.78 & 69.81 & 0.07 & 29.26 & 33.87 & 0.16 \\
\hline & $\mathrm{r} \leq 2$ & 38.52 & 47.85 & 0.27 & 22.31 & 27.58 & 0.20 \\
\hline & $\mathrm{r} \leq 3$ & 16.21 & 29.79 & 0.69 & 9.78 & 21.13 & 0.76 \\
\hline & $\mathrm{r} \leq 4$ & 6.42 & 15.49 & 0.64 & 5.30 & 14.26 & 0.70 \\
\hline & $\mathrm{r} \leq 5$ & 1.11 & 3.84 & 0.29 & 1.11 & 3.84 & 0.29 \\
\hline \multirow[t]{2}{*}{ LR estimates } & \multicolumn{3}{|c|}{$\mathrm{M} 2=1.47$ Remittance-0.72 GDP -0.32} & Inflation-0.11 & \multicolumn{2}{|c|}{ Openness +0.02 Real interest rate } & \\
\hline & & & $1)^{*} \quad(-1.97)^{*}$ & $(-4.69) *$ & ( 0.41) & $(\mathbf{1 . 7 7 )}$ & \\
\hline
\end{tabular}

Note. *denotes rejection of the hypothesis at least 5 percent significant level.

In the short run, remittance flows have positive impact but do not have statistically significant result at 5 percent level. Inflation and population growth have negative impact on growth but statistically insignificant. Since, the variables are co-integrated in the long run; there exists an error correction mechanism which brings together the long run relationship its short run dynamic adjustments. The error correction term, which measures the speed at which prior deviations from the equilibrium are corrected, has the correct negative sign and is significant at the 5 percent level in credit equation, however, indicating a relatively slow convergence to long-run equilibrium (Table 7). In deposit equation, error correction term is significant at 10 per cent level and indicating high convergence to long-run equilibrium compared to credit equation. Conversely, in money supply equation, error correction term has the correct negative sign but statistically insignificant which implies that if any shocks occur in the system then there is no adjustmentability towards equilibrium.

Table 7. Results for error correction model for financial development and remittances

Panel A. Dependent variable: $\triangle$ Credit

\begin{tabular}{llllllllll}
\hline ECM $_{t-1}$ & $\Delta$ Credit $_{t-1}$ & $\Delta$ Remi $_{t-1}$ & $\Delta G D P_{t-1}$ & $\Delta$ Inf $_{t-1}$ & soppen $_{t-1}$ & srealint $_{t-1}$ & Constant & Adj $^{2}$ & F-stat \\
\hline-0.05 & 0.47 & -0.26 & -0.70 & 0.08 & -0.10 & 0.02 & 0.04 & 33.13 & 1.62 \\
$(-2.71)^{*}$ & $(2.69)^{*}$ & $(-1.70)^{* *}$ & $(-0.57)$ & $(2.64)^{*}$ & $(-0.68)$ & $(2.11)^{*}$ & $(3.28)^{*}$ & & \\
\hline
\end{tabular}

Panel B. Dependent variable: $\triangle$ Bankdeposit

\begin{tabular}{llllllllll}
\hline ECM $_{t-1}$ & $\Delta$ Bankd $_{t-1}$ & $\Delta$ Remi $_{t-1}$ & $\Delta G D P_{t-1}$ & $\Delta$ Inf $_{t-1}$ & soppen $_{t-1}$ & srealint $_{t-1}$ & Constant & Adj $^{2}$ & F-stat \\
\hline-0.13 & 0.41 & 0.050 & -0.65 & -0.008 & -0.06 & -0.002 & 0.61 & 53.46 & 5.92 \\
$(-1.7)^{* *}$ & $(2.51)^{*}$ & $(0.75)$ & $(-1.49)$ & $(-0.53)$ & $(-1.07)$ & $(-0.67)$ & $(2.72)^{*}$ & & \\
\hline
\end{tabular}

Panel C. Dependent variable: $\triangle \mathrm{M} 2$

\begin{tabular}{llllllllll}
\hline$E C M_{t-1}$ & $\Delta M 2_{t-1}$ & $\Delta$ Remi $_{t-1}$ & $\Delta G D P_{t-1}$ & $\Delta$ Inf $_{t-1}$ & $\Delta$ oppen $_{t-1}$ & $\Delta$ realint $_{t-1}$ & Constant & Adj $^{2}$ & F-stat \\
\hline-0.041 & 0.13 & 0.10 & -0.45 & -0.017 & 0.012 & 0.003 & 0.003 & 17.23 & 1.89 \\
$(-0.66)$ & $(0.70)$ & $(0.94)$ & $(-0.49)$ & $(-0.59)$ & $(0.098)$ & $(0.44)$ & $(1.26)$ & & \\
\hline
\end{tabular}

Note. *denotes rejection of the hypothesis at the 5 percent significant level and ** denotes rejection of the hypothesis at the $10 \%$ level.

\subsection{Endogienity Test in Case of Financial Development}

This study, remittance-financed development model assumes that remittances are exogenously determined. However, it is perceived that remittances flow can be influenced by financial system of Bangladesh. Giuliano and Ruiz-Arranz (2009) indicate that, well-functioning financial markets, by lowering costs of conducting transactions, may help direct remittances to projects that yield the highest return and therefore, enhance growth rates. Apart from that, developed financial system led to higher remittance flow (Aggrawal et al., 2011). Thus, it can be argued that while the remittance flow potentially elevates the deposit base of a financial sector, the developed financial sector can also facilitate the higher inflow of remittance (Chowdhury, 2011). As mentioned earlier, to explore the endogenous association between remittance and financial development, we perform the Granger Causality test to examine whether financial development of Bangladesh is encouraging the rapid growth 
of remittance. The outcome of the test exhibit (Table 8) that bi-directional Granger Causality is present between remittance-deposit and remittance-money supply. This is the indication of improvement of the official remittance channels. It can be also argued that while the remittance flow potentially elevate the deposit base and money supply of a financial sector, the developed financial sector can also facilitate the higher inflow of remittance. At the same time, credit causes inflow of worker remittance but the reverse is not true. It is theoretically acceptable to all remittance recipient developing countries as the migrant workers send major share of their income to their country of origin irrespective of the financial development of the country or higher investment opportunities (Chowdhury, 2011).

Table 8. Pairwise granger causality test between remittance inflow and financial development

\begin{tabular}{llll}
\hline Null Hypothesis: & Obs & F-Statistic & Prob. \\
\hline Credit does not Granger Cause Remittance & 31 & $8.49^{*}$ & 0.00 \\
Remittance does not Granger Cause Credit & & 0.94 & 0.40 \\
Bankdepo does not Granger Cause Remittance & \multirow{2}{*}{31} & $3.93^{*}$ & 0.03 \\
Remittance does not Granger Cause Bankdepo & & $10.86^{*}$ & 0.00 \\
M2 does not Granger Cause Remittance & \multirow{2}{*}{31} & $6.36^{*}$ & 0.00 \\
Remittance does not Granger Cause M2 & & $3.36^{*}$ & 0.05 \\
\hline
\end{tabular}

Note. *denotes rejection of the hypothesis at least 5 percent significant level.

\section{Conclusion}

The aim of this study was twofold. It objective was to analyze the role of remittance on economic growth in Bangladesh and to investigate the interaction of migrant workers' remittance with the financial development of Bangladesh using annual data, relatively liberalized regime spanning from 1981 to 2013 . The remittance inflow has increased particularly over its liberalization period that began early eighties. At the same time, financial system of Bangladesh also began to thrive. This study employed the mostly used Johansen co-integration test along with vector error correction model to reveal both the short-run and the long-run association between remittance-growth and remittance-financed development. Granger Causality tests are also used to explore the possible endogenous relationship between remittance-growth and remittance-financed development. This study finds a long run positive relationship between inflow of remittance and gross domestic product indicating that remittance will be more likely to contribute to longer-term growth in Bangladesh. This paper also explores the relationship between financial development and inflow of remittances, focusing on the ratio of bank deposits, credit to private sector and money supply to GDP. It is revealed that remittances have a significant positive effect on financial development. Therefore, this study posits that the inflow of workers' remittance matters for countries like Bangladesh, which has a relatively growing economy and a developing financial sector. Exploring the possible endogenous relationship between remittance-growth and remittance-financed development provides some important linkages worth noting. We find that, growth causes remittance and credit causes inflow of workers' remittances but the reverse is not true. The outcome of the test also exhibits that bi-directional causalities are present between remittance-deposit and remittance-money supply. The empirical findings of this study, therefore, reveal that appropriate policy to proper management of migrant workers and more proficient use of remittance would help the economic development of Bangladesh. The findings of this study are robust and consistent with the existing literature using different econometric techniques, specification and sample as well.

\section{Policy Implications}

Since it is evidenced by this study that the inflow of migrant workers' remittance contribute to longer-term growth in Bangladesh and augment the measures of financial development such as credit, deposit and money supply, it is imperative for the policy makers to formulate and implement policies to encourage the migrant workers to remit through formal financial system which can be diverted to much needed productive investment ventures. The government of Bangladesh has taken a number of initiatives to enhance the inflow of remittance in official channel and achieved some remarkable progress in the field of overseas employment. These include expansion of the labor market, increased women employment with female labor migration from lagging regions of the country, digitalization in migration management, enhancement of welfare activities for the expatriates and their families, established a specialized bank "Expatriate Welfare Bank" (ProbashiKallyan Bank) for the expatriates to provide soft loans, non-resident foreign currency deposit, US dollar premium bonds, full tax exemption for the remittance income, and 'Overseas Employment and Migrant Act, 2013' to ensure strong and 
effective labor governance, better welfare services for expatriates, stopping harassment of workers by the middlemen, accountability, evaluation of the activities and penalize the recruiting agencies and ensure legal assistance to migrant workers. Nevertheless, along with these major initiatives, Bangladesh Government has to address the complex issues of managing the global demand for Bangladeshi migrant workers in line with the changing global economic situations and globalization as well. There are a number of important specific areas where improvements can be made and contributions from remittances to promote economic growth can be enhanced. Some of these areas are discussed below:

\subsection{Managing Migration and Remittances}

Creating the Ministry of Expatriates' Welfare and Overseas Employment and strengthening the "Bureau of Manpower , Employment and Training (BMET)", Bangladesh Government attempted to curtail the amount of undocumented migration and to ensure strong and effective labor governance, better welfare services for expatriates and stop harassment of workers by the middlemen. However, there is a scope to enhance the capacity such as full digitalization of the migration management, improving training techniques, enhancement of skills of these migrant workers and exploration of new labor markets for skilled as well as less skilled labor. Government may conduct a comprehensive review on the Bangladeshi labor market situation to identify labor supply from Bangladesh as well as labor demand in some of the major destination countries with particular emphasis on opportunities available and the challenges encountered by potential labor migrants from Bangladesh. In Bangladesh, data on outgoing migrants are recorded; however, there is no data to be found on returnee expatriates. It is, therefore, imperative to develop comprehensive 'Labor Migration Database' in order to assess the current labor migration trends and returning migrants for sustainable development and proper decision making in this sector.

It is undeniable that labor migration and remittance management is a complex subject and the government functionaries need to develop their understanding and level of expertise. As the labor market is competitive and creates a new dimension in the globalized market it is imperative to establish a new service pool to tackle the overseas employment affairs.

It is worth mentioning that low skilled workers are subjected to high migration costs and vulnerable to low pay and ill treatment as well. Skilled workers not only receive much higher pay but also enjoy the security of longer term employment opportunity. In case of challenging situations skilled workers are more appropriate both at the countries of origin and destination. In this consideration, Government may properly classify migrant population into different categories such as less skilled, semi-skilled, skilled and professional from international perspectives.

\subsection{Skilled Development of the Migrants}

The government of Bangladesh has given importance to skill development of both local and the migrant workers. Recently, 'Skills for Employment Investment Programme' has been undertaken. Steps should be taken in line with the proposed 'Skills for Employment Investment Programme'. Furthermore, focus has to be given to improve quality of training in such trades that are in demand both domestically and internationally. Emphasis should be given on language, behavior, culture, norms, values, working and geographical situation and so on before sending them abroad. The returned workers may help prospective workers by giving basic knowledge which will minimize the conflicts between employers and migrant workers that create a bad reputation of Bangladeshi workers. So, appropriate curricula are to be designed by resource persons who are qualified and has the necessary experience in the trades.

Recently, different crime allegations are reported against Bangladeshi workers in different countries, especially in the Middle-East. It is the prime time to minimize the allegations. Government may introduce a pre-departure training course on this legal issue.

It is noted that hospitality and tourism industry is undergoing rapid development creating major demands for young people with soft skills globally. Government may elevate the 'Hospitality Training Center' of Bangladesh Tourism Corporation and generate satellite training center in each large district. The government should create congenial atmosphere for public private partnership for establishing modern training facilities. The Philippines has successfully made a switch from low skilled migrants to skilled migrants. Bangladesh could follow the Philippines experiences.

\subsection{Proper Utilization of Remittances}

There is always a debate on proper use of remittance. In case of developing economies it is often observed that, most of the remittances are used towards the purchase of food, clothing, education, health and real estate and 
very little is targeted towards 'productive usage'. While the day-to-day spending can also be viewed as investment in human capital and increased future productivity, these positive effects are contingent on continuous flow of remittance over a long period of time (Guha, 2013). Thus, it is imperative to create appropriate investment opportunities according to the needs of the migrant workers'. One way of doing this is by investing in a large special project. Moreover, migrant workers' may invest in different business opportunities within their local towns that could create employment and growth opportunities. It is only possible if government offers incentives. These incentives could include public infrastructure and development in region centres to encourage remittance investment in these areas, as well as tax incentives for certain projects may be deemed suitable for development (Siddique, et al., 2012).

\subsection{Transmission Mechanisms of Remittances}

To minimize the informal channeling of remittance stronger institutional setup, reliable, rapid and low cost remittance transaction supports are needed. Indeed, the cost of remittance in Bangladesh is one of the lowest in the world due to some appropriate actions taken by the Government including strategic use of mobile financial services and partnership developed among banks, telecom companies and microfinance institutions. However, half of the remittance is still coming through unofficial channels (World Bank, 2006).

Increasing awareness, education and accessibilities to the financial services can foster the transfer of the valuable foreign exchange earnings into the financial sector. This support should endeavor to be easily accessible not only from centralized commercial areas but also households in rural areas. This would maximize remittances through in formal channels, at the same time foster growth in more disadvantaged rural areas. One such recommendation by Lasagabaster et al. (2005) is allowing established financial institutions to provide services through postal networks as a cost effective financial expansion measure. Moreover, Bangladesh Bank may think of different deposit options with banking institutions. Along with financial institutions, public institutions also play a significant role in the absorption process. They promote individual entrepreneurship through orientation programs and training, which leads to human capital formation (Guha, 2013). In addition to that, utilization of the media and use of other means of disseminating information should be explored to promote best practice in relation to the migration and remittance processes. This would also increase awareness of and confidence in the formal systems (Siddique, et al, 2012).

\section{5 'Dutch Disease' Effect}

It is certain that, there is a positive socio-economic effect of remittances; however, a large amount of remittances inflow may have adverse effects on the real exchange rates that may counteract. The government can reduce the adverse Dutch Diseases effect of remittances flow in the economy by increasing the trade competitiveness of Bangladesh. Moreover, government may design and implement relevant polices that can divert the remittances from the non-tradable sector to investment projects of the economy.

\subsection{The Structure of the Overall Economy}

Theoretically, it is believed that, outcomes of increased remittances are a decline of the traditional sector of the economy, which usually is the export competitive sector. This happens primarily because the traditional sector is usually labor intensive and with increased remittance inflows labor moves out of this sector creating a lack of productive capacity in the sector and hence a contraction of the sector. This difficulty can be avoided by diversification of the tradable sectors (Guha, 2013).

\subsection{Financial Incentives}

Policy initiatives such as the expansion of social programs in microfinance and skills development, and the lowering of interest rates on pre-departure loan schemes could provide necessary help for struggling households not yet meeting the initial cost of migration. More emphasis should be given to increase the number of workers from backward regions of the country. Government may allocate resources for providing soft loan to the migrant workers.

\subsection{Gender Issues}

The government has achieved an outstanding success in the area of female migration in the last five years. Between 2009 to 2013 about 0.17 million female workers migrated abroad, which shows a noteworthy improvement in the area of women migration. However, there are also significant gender issues that must be addressed if migration and remittance payments are to be effectively utilized. There are many problems faced by those women who manage to migrate (whether legally or not), with many reported cases of exploitation (Siddique et al., 2012). The United Nations notes that female migrants frequently face demands for higher payments from recruiting agents and are also often subject to assault by employers. Therefore, government may 
activate women's agencies, educate and train women, thereby increasing their capacity to cope with potential exploitation while gaining additional skills that can be used in the workplace. In addition to that, the government may provide financial incentives and bank loan (Low interest rates) to migrant female workers. More steps are to be taken to the enhancement of women employment with female labor migration from backward regions of the country.

\subsection{Returnee Expatriates}

In Bangladesh, data on outgoing migrants are recorded; however, there is no data to be found on returned expatriates. Therefore, proper attention should be given to returnee expatriates. The welfare activities for expatriates' workers and their family members have extended by the Government of Bangladesh. The Wage Earners Welfare Fund (WEWF) was established by the government in a bid to support migrants and their families in 1990. The size and scope of the Wage Earners Welfare Fund may be increased. The Philippines developed a fund where migrated and returnee expatriates' get different sorts of benefit like insurance and pension. Bangladesh may introduce the fund through WEWF.

\subsection{Integrated Migration and Remittances Policy}

International community has paid much attention in the past to finance, goods, and services movements. On the other hand, much less attention has been paid to the international movements of workers and remittances (Adams \& Page, 2005). It is noted that the migrants are often vulnerable to low and irregular payment of wages, poor living conditions, hazardous working conditions and scarce health care system. Therefore, it is obligatory to the World community to ensure the dignity and well-being of migrant people and to treat them as human beings, not the elements of economic activity or production. Furthermore, remittance sending cost is a common problem around the world and the cost is differing from country to country. The $5 \times 5$ objective was adopted by the G8 at the 2009 L'Aquila (Italy) summit to reduction of the global average total cost of migrant remittances by 5 percentage points in 5 years. Data published by 'Remittance Prices Worldwide' of World Bank indicate that a substantial reduction in the cost of making remittances. The simple average remittances cost fell to 8.4 per cent in the first quarter of 2014, compared to 9.1 per cent in 2013. The remittance sending costs are still behind expectations. So, there is every scope to strengthen the process.

There are a number of reasons for high transaction cost of sending remittance mainly due to lack of competition, regulation, and/or low levels of financial sector performance in labor-exporting countries act as a type of regressive tax on international migrants. International community should pay proper attention to reduction of the transactions costs of remittances. This will help enhance the poverty-reducing impact of international remittances and will also encourage a larger share of remittances to flow through formal financial channels.

It is, therefore, assumed that there would be substantial potential benefits to the world's poor if more international attention were focused on "Integrated Migration and Remittance Policy" within the larger global dialogue on economic development and poverty reduction. The government of Bangladesh may move forward for making an "Integrated Migration and Remittance Policy" through international dialogue. The "Integrated Migration and Remittance Policy" will try to address the migratory phenomenon from an integral and holistic perspective, including links to development, in order to maximize its benefits and minimize its negative effects.

\section{Acknowledgements}

Author is grateful to the anonymous referees and the editor of this journal for useful comments. I would like to thank Mr. Khairul Islam, Deputy Secretary to the Government of Bangladesh for his helpful comments on general readability and grammar. Opinions expressed in this paper are author's personal.

\section{References}

Adams, R., \& Page, J. (2005). Do international migration and remittances reduce poverty in developing countries? World Development, 33(10), 1645-1669. http://dx.doi.org/10.1016/j.worlddev.2005.05.004

Aggarwal, R., Demirguc-Kunt, A., \& Peria, M. S. M. (2011). Do remittances promote financial development. Journal of Development Economics, 96, 255-264. http://dx.doi.org/10.1016/j.jdeveco.2010.10.005

Ali, A., Imaia, S. K., Kaicker, N., \& Gaihab, R. (2014). Remittances, growth and poverty: New evidence from Asian countries. Journal of Policy Modelling, 36(3), http://dx.doi.org/10.1016/j.jpolmod.2014.01.009

Anderson, L. (2014). Migration, remittances and household welfare in Ethiopia. UNU-MERIT working paper series, ISSN 1871-9872.

Anyanwu, J. C., \& Erhijakpor, A. E. O. (2010). Do international remittances affect poverty in Africa? African 
Development Review, 22(1), 51-91. http://dx.doi.org/10.1111/j.1467-8268.2009.00228.x

Anzoategui, D., Asli, D. K., \& Peria, M. S. M. (2014). Remittances and Financial Inclusion: Evidence from El Salvador. World Development, 54, 338-349. http://dx.doi.org/10.1016/j.worlddev.2013.10.006

Bangladesh Bank. (2013). Wage Earners Remittance Inflows (Yearly). The Central Bank of Bangladesh, Government of the People's Republic of Bangladesh.

Bangladesh Bureau of Statistics (BBS). Retrieved from http://www.bbs.gov.bd/home.aspx

Barajas, A., Chami, R., Fullenkamp, C., Gapen, M., \& Montiel, P. (2009). Do Workers' Remittances Promote Economic Growth? Washington, D.C: IMF.

Bayangos, V., \& Jansen, K. (2011). Remittances and Competitiveness: The Case of the Philippines. World Development, 39(10), 1834-1846. http://dx.doi.org/10.1016/j.worlddev.2011.04.019

Boyd, J. H., Levine, R., \& Smith, B. (2001). The impact of inflation on financial sector performance. Journal of Monetary Economics, 47, 221-248. http://dx.doi.org/10.1016/S0304-3932(01)00049-6

Bruyn, T., \& Kuddus, U. (2005). Dynamics of remittances utilization. IOM Migration Research Series.

Buch, M. C., \& Kuckulenz, A. (2010). Worker remittances and capital flows to developing countries. International Migration, 48, 89-117. http://dx.doi.org/10.1111/j.1468-2435.2009.00543.x

Bureau of Manpower, Employment \& Training (BMET). Statistical Report. Retrieved from http://www.bmet.gov.bd/BMET/stattisticalDataAction

Chami, R., Fullenkamp, C., \& Jahjah, S. (2003). Are immigrant remittance flows a source of capital for development? IMF working paper WP/03/189.

Chami, R., Fullenkamp, C., \& Jahjah, S. (2005). Are immigrant remittance flows a source of capital for development? IMF Staff Paper, 52(1), 55-81.

Chowdhury, M. B. (2011). Remittances flow and financial development in Bangladesh. Economic Modelling, 28 , 2600-2608. http://dx.doi.org/10.1016/j.econmod.2011.07.013

Craigwell, R., Jackman, M., \& Moore, W. (2010). Economic volatility and remittances. International Journal of Development Issues, 9(1), 25-42. http://dx.doi.org/10.1108/14468951011033789

Giuliano, P., \& Ruiz-Arranz, M. (2009). Remittances, financial development, and growth. Journal of Development Economics, 90, 144-152. http://dx.doi.org/10.1016/j.jdeveco.2008.10.005

Gonzalo, J. (1994). Five alternative methods of estimating long-run equilibrium relationships. Journal of Econometrics, 60, 203-233. http://dx.doi.org/10.1016/0304-4076(94)90044-2

Guha, P. (2013). Macroeconomic effects of international remittances: The case of developing economies. Economic Modelling, 33, 292-305. http://dx.doi.org/10.1016/j.econmod.2013.04.016

Gupta, S., Powell, R., \& Yang, Y. (2009). Effect of remittances on poverty and financial development in Sub-Saharan Africa. World Development, 37(1), 104-115. http://dx.doi.org/10.1016/j.worlddev.2008.05.007

Johansen, S. (1991). Estimation and hypothesis testing of co-integrating vectors in Gaussian vector autoregressive models. Econometrica, 59, 1551-1580. http://dx.doi.org/10.2307/2938278

Jongwanich, J. (2007). Workers' remittances, economic growth, and poverty in developing Asia and the Pacific countries. UNESCAP working paper, WP/07/01.

King, R., \& Levine, R. (1993). Finance and growth: Schumpeter might be right. Quarterly Journal of Economics, 108, 717-737. http://dx.doi.org/10.2307/2118406

Kipyegon, L., Nyamongo, E. M., \& Misatib, R. N. (2012). Remittances, financial development and economic growth in Africa. Journal of Economics and Business, 64, 240-260. http://dx.doi.org/10.1016/j.jeconbus.2012.01.001

Kipyegonb, L., Misatib, R. N., Ndirangu, L., \& Nyamongoa, E. S. M. (2012). Remittances, financial development and economic growth in Africa. Journal of Economics and Business, 64, 240-260. http://dx.doi.org/10.1016/j.jeconbus.2012.01.001

Kumar, R. R. (2013). Remittances and economic growth: A study of Guyana. Economic Systems, 37, 462-472. http://dx.doi.org/10.1016/j.ecosys.2013.01.001

Love, I., \& Zicchino, L. (2006). Financial development and dynamic investment behavior: Evidence from panel 
VAR. The Quarterly Review of Economics and Finance, 46(2), 190-210. http://dx.doi.org/10.1016/j.qref.2005.11.007

Maimbo, M. S., \& Ratha, D. (2005). Remittances: Development Impact and Future Prospects. World Bank, Washington, D.C. http://dx.doi.org/10.1596/0-8213-5794-8

Misati, R. N., \&Nyamongo, E. M. (2011). Financial development and private investment in Sub-Saharan Africa. Journal of Economics and Business, 63(2), 139-151. http://dx.doi.org/10.1016/j.jeconbus.2010.10.001

Paul, B. P, Uddin, M. G. S., \& Noman, A. M. (2011). Remittances and output in Bangladesh: An ARDL bounds testing approach to co-integration. International Review of Economics, 58(2), $229-242$. http://dx.doi.org/10.1007/s12232-011-0120-2

Paul, B. P., \& Das, A. (2011). The Remittance-GDP Relationship in the Liberalized Regime of Bangladesh: Co-integration and Innovation Accounting. Theoretical and Applied Economics, 9(562), 41-60.

Rao, B. B., \& Hassan, G. M. (2011). A panel data analysis of the growth effects of remittances. Economic Modelling, 28, 701-709. http://dx.doi.org/10.1016/j.econmod.2010.05.011

Siddique, A., Selvanathan, S., \& Selvanathan, E. A. (2012). Remittances and Economic Growth: Empirical Evidence from Bangladesh, India and Sri Lanka. The Journal of Development Studies, 48(8), $1045-1062$. http://dx.doi.org/10.1080/00220388.2012.663904

Siddique, T. (2004). Institutionalizing Diaspora Linkage. The Emigrant Bangladeshis in UK and USA, MEWOE and IOM, Dhaka.

Uddin, G. S., \& Sjo, B. (2013). Remittances, Financial Development and Economic Growth in Bangladesh. South Asia Economic Journal, 4(2), 261-273. http://dx.doi.org/10.1177/1391561413500174

United Nations. (2013). Population Division, International Migration. Retrieved from http://esa.un.org/unmigration/wallchart2013.htm

World Bank. (2011). Migration and Remittances Fact book 2011 (2nd ed.). World Bank Publication.

World Bank. (2014). Remittance Prices. Worldwide, 9.

\section{Copyrights}

Copyright for this article is retained by the author(s), with first publication rights granted to the journal.

This is an open-access article distributed under the terms and conditions of the Creative Commons Attribution license (http://creativecommons.org/licenses/by/3.0/). 